\title{
Towards a Knowledge Building Community: From Guided to Self- Organized Inquiry
}

\section{Vers une communauté de coélaboration de connaissances : d'une recherche guidée à une recherche auto-organisée}

Stefano Cacciamani

\author{
Author \\ Stefano Cacciamani, Senior Researcher, at the University of Valle d'Aosta, Italy. \\ Correspondence regarding this article can be sent to s.cacciamani@univda.it
}

\begin{abstract}
Over four academic years a design experiment was conducted involving four online university courses with the goal of shifting from Guided to Self-Organized Inquiry to foster Knowledge Building communities in the classroom. Quantitative analyses focused on notes contributed to collective knowledge spaces, as well as reading and building-on notes of others. All team members, including teachers, contributed at high levels. Students tended to produce more notes in the guided-inquiry approach but read more and demonstrated more even distribution of work as part of self-organized inquiry. Qualitative data focused on strategies students reported as new to their school experience. Strategies fell into three categories common to both guided and self-organizing inquiry: elaborating course content for depth of understanding, collaboration in an online environment, and metacognition, with greater reflection on idea development. Distinctive aspects of self-organized inquiry, according to student reports, included going beyond given information, linking new understandings and personal experiences, attention to the collective works of the community, and learning from instructor's strategies.
\end{abstract}

\section{Résumé}

Pendant quatre ans, une expérience a été menée impliquant quatre cours universitaires en ligne. L'objectif était de passer d'une recherche guidée à une recherche auto-organisée par l'apprenant afin de contribuer à la construction de communautés de savoir dans la classe. Des analyses quantitatives ont porté sur les notes produites dans les espaces collectifs de savoir et sur la lecture et l'enrichissement de notes déjà existantes. Tous les membres de l'équipe, incluant les professeurs, ont contribué au projet de façon active. Les étudiants avaient tendance à produire plus de notes lorsque sous l'approche guidée, mais lisaient davantage et divisaient le travail plus équitablement lorsqu'ils s'organisaient eux-mêmes. Les 
données qualitatives mettent l'accent sur les stratégies auxquelles les étudiants n'avaient pas été exposés auparavant dans leur expérience scolaire. Les stratégies se divisaient en trois catégories, communes à la recherche guidée et à la recherche autoorganisée, soit l'élaboration de contenu de cours pour une compréhension approfondie, la collaboration à un environnement en ligne et la métacognition, qui comprend une plus grande réflexion sur le développement des idées. Des aspects distincts de la recherche auto-organisée comprenaient le fait d'aller au-delà des informations fournies, d'être en mesure d'établir des liens entre de nouvelles compréhensions et ses expériences personnelles, de s'intéresser aux travaux collectifs de la communauté et d'apprendre à partir des stratégies d'apprentissage de l'instructeur.

\section{Introduction}

Preparing students for a knowledge society requires improving their ability to work creatively with ideas (Bereiter \& Scardamalia, 2003). This, in turn, requires shifting from traditional practices to a knowledge construction perspective (De Kock, Sleegers, \& Voeten, 2004; Lowyck \& Ellen, 1993). A metaphor for traditional practice is mind as a container (Bereiter, 2002). The role of the teacher is to add content to the container. This often leads to "inert knowledge"-knowledge that cannot be applied or used to address problems. Current constructivist perspectives focus more on learning as a meaningful experience achieved through constructive, situated and collaborative activities within a community (Simons, 2000). Constructive learning takes place when an individual "manipulates" new knowledge and actively connects it to what he/she already knows. This process is advanced through an awareness that knowledge is not a static object to be received, but a system of "conceptual artefacts" (Bereiter, 2002) to be elaborated and improved in connection to real contexts of practices. Learning is then a situated social process; knowledge is a socio-cultural construction created by individuals engaged in social activities (Driscoll, 2000; Wenger, 1998).

A contrast between these two different perspectives of instruction can be found in universities that are introducing online courses for their students. Many researchers highlight the positive effects of the social constructivist perspective (Hsu, 2004) and point out that discussions taking place in online environments can promote the understanding of learning content through the integration of different and conflicting points of view (Hoadley \& Linn, 2000; Linn, Davis, \& Bell, 2004). Furthermore, these environments can promote conceptual change (Fishman \& D'Amico, 1994) and metacognition (Park, 1999). Metacognition is especially important for creative work with knowledge. The term was coined to convey reflective processes entailed in knowledge about cognitive activity-the knowledge an individual has about cognitive processes (Flavell, 1981; Flavell \& Wellman, 1977) and the active control of those processes (Brown, 1978). Available literature additionally suggests that online work encourages students to use new problem-solving strategies (Herrington, Oliver, \& 
Reeves, 2003) and to support the development of social interaction skills that are useful in work-groups (Edelson, 2001; Krajcic, 2000).

Despite the reported benefits of a social constructivist perspective implied by online work, researchers note that while there is a substantial increase in fully online and blended courses offered at many universities (Allen \& Seaman, 2003; American Federation of Teachers, 2001), the majority of these courses are still linked to a "knowledge transmission" rather than knowledge construction perspective (Reeves, Herrington, \& Oliver, 2004). So an important question is: how is it possible to shift the activity of a group in an online environment towards a knowledge construction perspective?

An interesting opportunity in this sense is offered by the implementation in online courses of the Knowledge Building community model created by Carl Bereiter and Marlene Scardamalia (Scardamalia \& Bereiter, 1999) and described by 12 principles (Scardamalia, 2002;

Scardamalia \& Bereiter, 2006, present issue). Three assumptions underlie these principles, as applied in the current context.

\section{Knowledge is a socio-cultural artefact, socially distributed:}

Bereiter and Scardamalia refer to the distinction by Popper (1972) whereby three worlds of knowledge are defined: World 1, physical reality; World 2, reality existing in mental representations of the individuals; and World 3, knowledge as a system of theories, considered as socio-cultural conceptual artefacts shared among people and within the social community. This third world of knowledge should be the object of interest for the school system, in which the activity should be focused not only on the acquisition of knowledge by the individual (World 2), but also on the re-orientation and assimilation of knowledge so that every student is an enabled contributor to their community (Scardamalia, Bereiter, \& Lamon, 1994).

\section{The class is a community with collective responsibility to build knowledge:}

The class, here re-defined as a Knowledge Building community, commits to producing valuable ideas for the community, and shares collective responsibility for improving those ideas. Accordingly, each member undertakes both to achieve a good performance in their individual work and to improve the ideas to be put at the community's disposal (Scardamalia \& Bereiter, 1999).

\section{The students and teacher are knowledge builders, each involved in the Knowledge Building process:}

The participants in Knowledge Building community undertake the responsibility of the Knowledge Building process and the commitment to investigate and discuss activities based on real ideas and authentic problems. The goal thus becomes the progressive refinement of 
ideas and the building of increasingly complex theories concerning topics and problems connected to the tasks to be fulfilled. Each member monitors the effectiveness of the work, with the goal of improving it and the teacher undertakes to turn increasing levels of responsibility over to students (Bereiter, Scardamalia, Cassels, \& Hewitt, 1997).

The design experiment to be reported addressed the challenge of helping students assume a more profound "knowledge construction" perspective. In particular we analyze designs for an online course as it evolved over four years, from guided to self-organized inquiry.

Most pedagogical approaches, including those committed to a knowledge construction, use some variant of guided inquiry or guided discovery, and in most implementations high-level parts of the inquiry are under teacher control. For example the teacher typically sets the goals, monitors progress, redirects inquiry if things are not going well, and so forth. Knowledge Building, in contrast, is defined by students' abilities to take on high-level functions essential to knowledge creation and the creative work with ideas Knowledge Building requires (Scardamalia, 2002). Accordingly, the teacher's challenge is to find increasingly more effective ways to turn over greater responsibility to the students. Thus objectives, research questions, assessments, experiments, and so forth are developed by students, as their inquiry progresses. As a result students come to understand the emergent and progressive nature of Knowledge Building (see Chuy et al., present issue) rather than working continuously in environments in which most of the work is predetermined. These practices follow from Knowledge Building principles. As Scardamalia and Bereiter (2003) have argued, knowledge creation represents deep constructivism, requiring a shift from shallow to deep constructivist processes associated with each Knowledge Building principles (Scardamalia, 2002; Scardamalia \& Bereiter, 2006, present issue).

To understand the design experiment in this research it is important to appreciate the context for the work. The University of Valle d'Aosta, where the work took place, opened in 2000 and the first online course at the university was the 2002, undergraduate course described below. The instructor, while understanding at a conceptual level the importance of shifting from guided inquiry to self-organized inquiry, had never actually designed a course to effect such change. Constraints and possibilities for implementing the shift became clearer as the work proceeded. For example, more control was in the teacher's hands than necessary in early implementations, and later developments represented efforts to turn over more control and responsibility to student. It is now clearer how future implementations might turn over even greater responsibility to students. Thus this work is best viewed as small-scale design experimentation (Collins, Joseph, \& Bielaczyc, 2004; The Design-Based Research Collective, 2003 ). Each course format was repeated for two years due to small sample sizes and a shift from year 1 to year 2 in the content of the course.

Analyses focus on quantitative indicators of process and change (patterns of contribution, reading, and building on). Qualitative analyses focus on students' perception of change as reflected in strategies they report as new to their classroom work. 


\section{Method}

\section{Participants}

The data for this study came from four different online courses conducted from 2002 to 2006 in the Faculty of Psychology of the University of Valle d'Aosta. The first course, academic year 2002-2003, was Developmental Psychology and was attended by five students; the following three courses were Educational Psychology and were attended by four students in 20032004, six students in 2004-2005, five students in 2005-2006. All students were undergraduates between 25 and 40 years of age. In addition, each course included the teacher and a tutor, collectively referred to below as instructors.

\section{Online environment}

Knowledge Forum ${ }^{\circledR} 4.5$ was used for each of the four courses, as the communal space to which all students contributed notes, using text or graphics. Notes are organized in views, and in this study the view was the space to which notes about a specific topic were contributed. Every authorized user connects to the database, contributes notes, reads the notes of other participants, builds on the notes of others, and links notes in various ways. Build-ons serve to develop the idea in a previously contributed note. Every user can also decide to organize notes in a view, reflecting the principle of community knowledge, collective responsibility, and use a special note called "rise above" to synthesize notes, in line with the rise-above principle.

\section{Design}

To develop the implementation of the Knowledge Building community in the online courses at the University of Valle d'Aosta we used a design-based research perspective, reflecting a commitment to understanding and changing the relationships between theory and practice, and design work required to foster such change. Following this perspective, the Knowledge Building community model was developed in two phases, the first during the two-year period of 2002-2003 and 2003-2004 and the second during another two-year period, 2004-2005 and 2005-2006.

\section{Guided Inquiry}

The Developmental Psychology course in the academic year 2002/2003 was the first online course at the University of Valle d'Aosta, with the following organizational aspects: 


\section{1) Introduction to Knowledge Building pedagogy and technology.}

At the beginning of the course a meeting was held to explain the principles of a Knowledge Building community. Responsibility for development of the community knowledge was highlighted, and Knowledge Forum was introduced as a community space.

\section{2) Questions of inquiry and dialogical structure.}

The course was articulated in nine weeks and divided into five modules, corresponding to the five parts of the program. Each module was introduced through a face-to-face meeting and a view in Knowledge Forum was created with two notes, each one containing a question of inquiry related to the concept introduced. For example, the question concerning Bowlby's Theory of Attachment was: "How is it possible to use this theory to favor an effective experience, from the educational point of view, for children in kindergarten? The participants had two weeks to develop their ideas for each module, taking information from the course books and from readings they identified on their own. One note for each of the five modules was compulsory.

\section{3) Teacher and tutor as research participants.}

The role of the teacher was to participate in the evolution of the inquiry using his competence regarding the theoretical models; the tutor's role was to facilitate the online interaction with regard to Knowledge Forum and to support the process of inquiry using his competence in the application fields (e.g., experience about the kindergarten and school context). The role of both the tutor and the teacher was designed with reference to the democratizing knowledge principle: each of them participated in the activity with the students, with everyone working to advance their own ideas and those of their peers.

\section{4) Rise above.}

There is a rise-above note within Knowledge Forum specially designed to support high-level syntheses. Two days before the meeting, the tutor prepared this rise-above note to convey the main ideas emerging from the discussion during the two weeks. During a face-to-face meeting the students read the rise-above notes and formulated unsolved questions for discussion in the face-to-face meeting.

\section{5) Strategic activity:}

In a final course activity designed to engage students in evaluation and metacognitive reflection, as well as to provide input regarding what students perceived as new, students were asked to identify new strategies that they experimented with in the course. The second year online course of Educational Psychology, academic year 2003-2004, replicated the year-1 course. It was organised into four modules with the contribution of a note for each module 
being compulsory. The instructors took a guiding role in determining inquiries and created rise-above notes. Thus these two implementations are best viewed as guided as opposed to self-organizing inquiry.

As will be discussed in the upcoming section dealing with the qualitative analyses, students reported greater engagement with course content, collaboration, and metaperspective than they had been accustomed to in previous courses. However, instructor reflection regarding course dynamics, in light of the dimension of shallow-versus-deep constructivism introduced previously, it seemed clear that the implementation was at the shallower end of this continuum. It was not in keeping with self-organizing systems (see Hong, Scardamalia, and Zhang, present issue). Next-generation designs were formulated to achieve deeper levels of Knowledge Building principles

\section{Self-Organized Inquiry: First Steps}

In the third year, online Educational Psychology course, academic year 2004-2005, we placed greater emphasis on student responsibility-the community knowledge, collective responsibility principle. The course procedures were the same, with the exception of the following two features:

1. Questions of inquiry were defined by students: in order to support the epistemic agency principle, students worked in pairs or groups of three to define questions for inquiry.

2. Rise above created by the students: to advance rise-above the embedded and transformative assessment principles (Scardamalia, 2003) , we asked each participant, at the end of each module, to create a rise-above note highlighting the main ideas developed and a question still unanswered. Both the online courses of Educational Psychology were composed of four modules and a rise-above note for each module was compulsory.

\section{Observed variables}

\section{Quantitative indicators of student activity: writing, reading, and building-on.}

Quantitative measures used in this study are presented briefly below:

1. Average number of notes written by each participant. These were used to characterize student contributions to the online community space.

2. Percentage of total notes read by each participant. This measure provides indication of the efforts of students to form as a community, with the work of their peers important to course interactions. 
3. Percentage of each author's notes that were build-ons. This provides indication of elaboration of ideas already in the communal space

In each of the four courses the teacher and the tutor were very active-they wrote on average several notes more than the students and read more than $88 \%$ of the notes written. They were also very interactive, with $80 \%$ of their notes in each course build-ons. They clearly contributed as fully-functioning members of the community.

\section{Qualitative Analysis-Strategies students report as novel to their work in the course}

A grounded theory approach by the author of this paper was used to identify the strategic actions for students' self-reported strategies. Three dimensions were identified in student responses: Explore and Elaborate Course Content, Collaboration, and Metacognition. Subcomponents were then identified for each strategic action. The strategic actions and subcomponents listed in Table 1 provide an exhaustive classification of all statements from students. Following this grounded theory analysis the work shifted more to a case study design to determine whether there were perceptible shifts in students' reports of new strategies, so that different raters could reliably identify the major strategic actions-and subcomponents. There was reasonably high agreement in identifying both the major strategic actions (85.4\% agreement) and subcomponents (71.4\%). Disagreements were discussed until agreement was reached (the second coder was not aware of the different conditions under which the data were generated). The identified strategic actions and their subcomponents are presented in Table 2. 
Table 1: Student-reported use of new strategies to address course needs and opportunities

\begin{tabular}{ll}
\hline Strategic Action & Subcomponents \\
\hline A) Explore and Elaborate Course Content & A1) Self questioning; \\
& A2) Managing a research activity (through \\
face-to-face meeting, Internet, etc.); & A3) Connecting course content to personal \\
ideas or experience; providing examples; & A4) Re-reading and reflecting on texts, topics, \\
etc.; \\
A5) Building interdisciplinary connections; \\
A6) Synthesizing entries in Knowledge Forum. \\
A7) Posing questions to the teacher and \\
colleagues.
\end{tabular}

B) Collaboration

B1) Posing and receiving challenges to ideas;

B2) Building on, annotating, referencing, and organizing entries in Knowledge Forum.

C) Metacognition

C1) Tracking changes in work over time;

C2) Monitoring change in knowledge;

C3) Perceiving and modelling instructor strategies.

\section{Data analysis}

For quantitative data analysis we used Knowledge Forum's Analytic Toolkit that makes it possible to track interactions among students in the online environment and provides a basic descriptive level of analysis. Qualitative data analysis required building a coding scheme to identify strategic actions students reported as new in the way they approached the course.

Our goal was to determine if there were differences reported between the guided and selforganized inquiry. 


\section{Results}

\section{Quantitative Indicators of Student Activity: Writing, Reading, and Building-On}

The average number of notes written by the participants in each course (see Table 2) exceeds the compulsory number (one note for each module was compulsory: in total five notes in the first course and four notes in the others). There are different patterns which appear between the two types of courses: the mean and the standard deviation of notes contributed is higher in the guided-inquiry approach, but the variation is greater for this model, with few students very active; in the self-organized inquiry model contributions are more evenly distributed. With respect to notes read, the percentage is high in all courses (ranging from $79.6 \%$ to $90.16 \%)$, and higher and more equally distributed in the self-organized inquiry model.

Table 2: Quantitative Indicators of Student Activity: Writing, Reading, and Building-On

\begin{tabular}{|c|c|c|c|c|c|c|c|c|c|c|}
\hline & \multicolumn{2}{|c|}{$\begin{array}{l}\text { Number of } \\
\text { participants }\end{array}$} & \multicolumn{2}{|c|}{$\begin{array}{l}\text { Total number of } \\
\text { notes written }\end{array}$} & \multicolumn{2}{|c|}{$\begin{array}{l}\text { Notes Written } \\
\text { Average number of } \\
\text { notes written by } \\
\text { each participant } \\
\text { (Standard } \\
\text { deviation) }\end{array}$} & \multicolumn{2}{|c|}{\begin{tabular}{|l|} 
Notes Read \\
Percentage of total \\
notes read by each \\
participant \\
(Standard \\
deviation)
\end{tabular}} & \multicolumn{2}{|c|}{$\begin{array}{l}\text { Creating Build-ons } \\
\text { Percentage of } \\
\text { each author's } \\
\text { notes that are } \\
\text { build-ons } \\
\text { (Standard } \\
\text { deviation) }\end{array}$} \\
\hline & Students & Teachers & Students & Teachers & Students & Teachers & Students & Teachers & Students & Teacher \\
\hline $\begin{array}{l}1^{\text {st }} \text { course: } \\
\text { Guided Inquiry } \\
\text { Developmental } \\
\text { Psychology } \\
\text { A.Y. 2002-2003 }\end{array}$ & 5 & 2 & 158 & 130 & $\begin{array}{c}31.6 \\
(35.5)\end{array}$ & $\begin{array}{c}65 \\
(35)\end{array}$ & $\begin{array}{l}79.6 \% \\
(22.14)\end{array}$ & $\begin{array}{c}97.5 \% \\
(0.5)\end{array}$ & $\begin{array}{c}97.4 \% \\
(3.5)\end{array}$ & $\begin{array}{c}82 \% \\
(5)\end{array}$ \\
\hline $\begin{array}{l}2^{\text {nd }} \text { course: } \\
\text { Guided Inquiry } \\
\text { Educational } \\
\text { Psychology } \\
\text { A.Y. 2003-2004 }\end{array}$ & 4 & 2 & 167 & 101 & $\begin{array}{l}41.75 \\
(50.9)\end{array}$ & $\begin{array}{c}50.5 \\
(32.5)\end{array}$ & $\begin{array}{l}82.5 \% \\
(18.6)\end{array}$ & $\begin{array}{c}100 \% \\
(0)\end{array}$ & $\begin{array}{l}93 \% \\
(5.9)\end{array}$ & $\begin{array}{c}78 \% \\
(6)\end{array}$ \\
\hline $\begin{array}{l}3^{\text {rd }} \text { course: } \\
\text { Self-Organized } \\
\text { Inquiry } \\
\text { Educational } \\
\text { Psychology } \\
\text { A.Y. 2004-2005 }\end{array}$ & 6 & 2 & 53 & 47 & $\begin{array}{c}8.83 \\
(1.72)\end{array}$ & $\begin{array}{l}23.5 \\
(9.5)\end{array}$ & $\begin{array}{c}90.16 \% \\
(9.82)\end{array}$ & $\begin{array}{c}89 \% \\
(7)\end{array}$ & $\begin{array}{l}44.33 \% \\
(19.74)\end{array}$ & $\begin{array}{l}81 \% \\
(10)\end{array}$ \\
\hline $\begin{array}{l}4^{\text {th }} \text { course: } \\
\text { Self-Organized } \\
\text { Inquiry } \\
\text { Educational } \\
\text { Psychology } \\
\text { A.Y. 2005-2006 }\end{array}$ & 5 & 2 & 121 & 85 & $\begin{array}{c}24.2 \\
(10.8)\end{array}$ & $\begin{array}{c}42.5 \\
(29.5)\end{array}$ & $\begin{array}{c}89 \% \\
(14.6)\end{array}$ & $\begin{array}{c}88.5 \% \\
(7.5)\end{array}$ & $\begin{array}{l}78.8 \% \\
(9.47)\end{array}$ & $\begin{array}{c}94 \% \\
(2)\end{array}$ \\
\hline
\end{tabular}

Towards a Knowledge Building Community 
The percentage of each author's notes that are build-ons are higher for the guided-inquiry model and more equally distributed compared to self-organized inquiry.

\section{Qualitative Analysis-Strategies students report as novel to their work in the course}

The strategic actions that students identify as new with respect to different facets of guided and self-organized inquiry are not new in the sense of being novel or innovative in educational literature or educational contexts; what is interesting is what students perceive as new in contrast to previous courses. Below we clarify core themes for the three major categories in the coding scheme presented in Table 1. Then an overview of contrasts is presented, to convey what was, from the students' perspectives, the most salient differences between the guided and self-organized inquiry. To convey these contrasts students' verbatim accounts are presented, followed in the discussion section by a brief analysis of how guided versus self-organizing inquiry presumably led to these perceived differences.

\section{Explore and Elaborate Course Content}

Students in both groups reported greater effort than in other courses committed to understanding and comprehending course content. What is distinctive to the self-organized inquiry is reflection on advancing ideas, efforts to go beyond the information as given, and greater attention to linking new understandings to personal experiences. These distinguishing characteristics of the self-organized inquiry are reflected in the following statements (codes A3, B1, etc. indicate correspondences to the coding scheme presented in Table 1):

The participation to Knowledge Forum forced me to reflect on the argument presented in each phase... (A4) and to find connections with my experience, allowing me at the same time to internalize better the concepts and to deepen them. (A3)

This online course allowed me to know the argument presented by the teacher during the face-to-face meeting and then to deepen that at home. In this way it was possible to reflect more about that (A4) and to connect it (arguments) to my experiences. (A3)

Through these means there seems to be greater emphasis on continuing use and application of theories and new ideas. 


\section{Collaboration}

With reference to collaboration, the need to externalize thinking was noted, with corresponding need for higher levels on interaction with ideas of others. The students of the self-organized inquiry mode show, in addition, the need to process information in new and more demanding ways:

Then, the most important thing, to compare what I learned with other people, that led to strengthen my opinions and sometimes, to a partial perturbation of my ideas. Very stimulating!!! "(B1)

Another student stated:

As methodological strategy, the method of KBC [Knowledge Building community] obliged me to build knowledge in a shared way, and stimulated to deepen the topic using the books that in this way became a bi-dimensional, dialogical tool - between person and knowledge, and tri-dimensional-person, group and knowledge. (B1)

There also seemed to be greater emphasis in the self-organized inquiry group on managing time and dealing with the "rhythm of the conversation.

Then it was necessary to organize the time. I recognised in the contributions the typical rhythm of the conversation (listening and speaking) and I distinguished the two moments preferring the reading activity if I had less time (then I connected to Knowledge Forum from the workplace, I copied the notes and I read and re-read all the time - It was necessary), when I was quiet, having more "time" I managed the writing activity. (B2)

\section{Metacognition}

A common theme is that of tracking changes over time and developing awareness about changes in state of knowledge. What seemed most distinctive to the self-organized inquiry approach is what students learned from observation of the instructors' strategies:

I tried to discover the techniques of the tutor: for instance in each module we presented a question, the tutor "provoked" in a critical manner the discussion trying to contextualize, to make it in a concrete way, and then the teacher "opened", gave a first signal of the direction. None of us, was able to give a contribution before this scheme, sometimes only for some work commitments. This allowed me to SEE your (NoT: of teacher and tutor) strategy in actions. In this moment I don't remember the introduction of data creating a contradiction, but I can say that it was a circular attention to the discussion where almost every note received feedback. (C2) 


\section{Discussion}

In early guided-inquiry implementations of the course, the activity of the group was directed by the teacher and tutor. In fact, both the teacher and the tutor defined the questions of inquiry and the tutor prepared the rise-above note to convey knowledge advancements. In contrast, in the self-organized inquiry implementations, students defined the questions for inquiry, organized themselves into two and three person teams, and prepared rise-above notes.

Students in all implementations contributed more than the compulsory number of notes and read extensively in the communal space. In the guided-inquiry implementation the students wrote more but there was substantial variability in how much they wrote, whereas the distribution was more even in the self-organized inquiry. High variability may indicate that some students were not drawn to the specific content of the teachers' questions, nor able to link it to personal experiences as in the self-organized inquiry approach. With respect to reading notes, there was greater, and more evenly distributed activity with self-organized inquiry, seemingly reflecting greater interdependence in defining inquiries. In contrast, buildon was higher and more distributed in the guided-inquiry mode, seemingly because in the self-organized inquiry mode students were free to define their inquiries, and thus explore more new directions.

Both groups reported new and more demanding strategies for processing course content, collaborating, and engaging in reflective activities, especially with respect to changing ideas over time. Distinctive aspects of self-organized inquiry, according to students' reports, included efforts to go beyond the information as given, linking new understandings to personal experiences, processing information in more demanding ways, and learning from instructor strategies.

In conclusion, regarding the implementation of a Knowledge Building community in an online university course, there is a suggestion in the early pilot work reported, that the selforganized inquiry approach favours a shift towards a knowledge construction perspective more so than the guided-inquiry approach

Future directions for research include a more detailed analysis of the self-organized inquiry using Content Transcript Analysis (Garrison, Cleveland-Innes, Koole, \& Kappelman, 2006) to identify aspects of Knowledge Building discourse that are particularly effective, as well as research into student motivation. In the current study, while students in the self-organized inquiry implementation defined their own inquiries and produced rise-above summary notes, they did so within a predetermined framework. Also, while they were engaged in readings beyond those identified by the course instructor, these other sources of information were underrepresented in course work. Next iterations of this design research will require less predetermination of organizational structure and content and working with larger numbers of students, with higher levels of student engagement relative to teacher engagement. 
Knowledge Forum scaffolds (see Chuy et al., present issue) may also be introduced to advance depth of inquiry to support high-level functions for sustained knowledge construction.

\section{Acknowledgements}

I would like to express my gratitude to the University of Valle d'Aosta for funding the development of the online courses that are the focus of this research. I am grateful for insightful reviews that helped me revise the present paper

\section{References}

Allen, I. E. \& Seaman, J. (2003). Sizing the opportunity: The quality and extent of online education in the United States, 2002-2003. Needham, MA: The Sloan Consortium.

American Federation of Teachers (AFT) (May 2000). Distance education: Guidelines for good practice [Online]. Retrieved November 2003 from http://www.aft.org/higher_ed/downloadable/distance.pdf

Bereiter, C. (2002). Education and mind in the knowledge age. Hillsdale, NJ: LEA.

Bereiter, C., \& Scardamalia, M. (2003). Learning to work creatively with knowledge. In E. De Corte, L. Verschaffel, N. Entwistle, \& J. V. Merrienboer (Eds.), Powerful learning environments: Unravelling basic components and dimensions (pp. 73-78). Oxford: Elsevier Science.

Bereiter, C., Scardamalia, M., Cassels, C., \& Hewitt, J. (1997). Postmodernism, Knowledge Building and elementary sciences. The Elementary School Journal, 97(4), 329-340.

Brown, A. L. (1978). Knowing when, where and how to remember: A problem of metacognition. In R. Glaser (Ed.). Advances in instructional psychology (Vol.1, pp. 225253). Lawrence Erlbaum, Hillsdale, NJ.

Chuy, M., Scardamalia, M., Bereiter, C., Prinsen, F., Resendes, M., Messina, R., Hunsburger, W., \& Teplovs, C. (2010). Understanding the nature of science and scientific progress: A theory-building approach. Canadian Journal of Learning and Technology, 36(1).

Collins, A., Joseph, D., \& Bielaczyc, K. (2004). Design research: Theoretical and methodological issues. Journal of the Learning Sciences, 13(1), 15-42.

De Kock, A., Sleegers, P., \& Voeten, M. J. M. (2004). Learning and classification of learning environments in secondary education. Review of Educational Research, 74(2), 141-170.

Driscoll, M. P. (2000). Psychology of learning for instruction ( $2^{\text {nd }}$ ed.). Boston: Allyn and Bacon. 
Edelson, D. C. (2001). Learning-for-use: A framework for the design of technology-supported inquiry activities. Journal of Research in Science Teaching, 38, 355-385.

Fishman, B. J., \& D'Amico, L. M. (1994). Which way will the wind blow? Networked computer tools for studying the weather. Dublin, $\mathrm{OH}$ : Online Computer Library Center, Inc. (ERIC Document Reproduction Service No. ED388245).

Flavell, J.H. (1981). Cognitive monitoring. In W.P. Dikson (Ed.) Children's oral communication skills (pp. 35-60). Academic Press, New York.

Flavell, J. H., \& Wellman, H. M. (1977). Metamemory. In R. V. Kail \& J. W. Hagen (Eds.), Perspectives on the development of memory and cognition (pp. 3-33). Lawrence Erlbaum, Hillsdale, NJ.

Garrison, D. R., Cleveland-Innes, M., Koole, M., \& Kappelman, J. (2006). Revisiting methodolocal issues in transcript analysis: Negotiated coding and reliability. The Internet and Higher Education 9(1), 1-8.

Herrington, J., Oliver, R., \& Reeves, T. C. (2003). Patterns of engagement in authentic online learning environments. Australian Journal of Educational Technology, 19(1), 59-71.

Hoadley, C.M., \& Linn, M. C. (2000). Teaching Science through online peer discussion. A speakeasy in the knowledge integration environment. International Journal of Science Education, 22, 839-857.

Hong, H. Y., Scardamalia, M., \& Zhang, J. (2010). Knowledge Society Network: Toward a dynamic, sustained network for building knowledge. Canadian Journal of Learning and Technology, 36(1).

Hsu, Y. S. (2004). Using the Internet to develop students' capacity for scientific inquiry. Journal Educational Computing Research, 31(2), 137-161.

Krajcic, J. S. (2000). Advantages and challenges of using the World Wide Web to foster sustained scientific inquiry in middle and high school classrooms. $8^{\text {th }}$ International Conference on Computer Assisted Instruction, Taipei, Taiwan.

Linn, M. C., Davis, E. A., \& Bell, P. (2004). Internet environments for science education. Mahawah, NJ: LEA.

Lowyck, J., \& Ellen, J. (1993). Transitions in the theoretical foundation of instructional design. In T. M. Duffy, J. Lowyck, \& D. H. Jonassen (Eds.), Designing environments for constructive learning (pp.213-230). New York: Springer-Verlag.

Park, M. J. (1999). The effect of a shared intranet science learning environment on academic behaviour. Dublin, OH: On-line Computer Library Center, Inc. (ERIC Document Reproduction Service No. ED432274). 
Popper, K. R. (1972). Objective knowledge: An evolutionary approach. Oxford: Clarendon Press.

Reeves, T. C., Herrington, J., \& Oliver, R. (2004). A developmental research Agenda for online collaborative learning. Educational Technology Research and Development, 52(4), 5365.

Scardamalia, M. (2002). Collective cognitive responsibility for the advancement of knowledge. In B. Smith (Ed.), Liberal education in a knowledge society (pp. 67-98). Chicago: Open Court.

Scardamalia, M. (2003). Going beyond best practice: Knowledge Building principles and indicators. Paper presented at Summer Institute - August 2003 - University of Toronto.

Scardamalia, M., \& Bereiter, C. (1999). Schools as knowledge-building organizations. In D. Keating \& C. Hertzman (Eds.), Today's children, tomorrow's society: The developmental Health and Wealth of Nations (pp. 274-289). New York, NY: Guilford.

Scardamalia, M., \& Bereiter, C. (2003). Knowledge Building. In Encyclopedia of education (2nd Ed.) (pp.1370-1373). New York: Macmillan Reference.

Scardamalia, M., \& Bereiter, C. (2006). Knowledge Building: Theory, pedagogy, and technology. In K. Sawyer (Ed.), Cambridge Handbook of the Learning Sciences (pp. 97118). New York: Cambridge University Press.

Scardamalia, M., \& Bereiter, C. (2010). A brief history of Knowledge Building. Canadian Journal of Learning and Technology, 36(1).

Scardamalia, M., Bereiter, C., \& Lamon, M. (1994). The CSILE project: Trying to bring the classroom into world 3. In Kate McGilly (Ed.), Classroom lessons: Integrating cognitive theory and classroom practice (pp. 201-228). Cambridge, MA: Bradford Books/ MIT Press.

Simons, P. R. J. (2000). Towards a constructivist theory of self-directed learning. In G. A. Straka (Ed.), Conceptions of self-directed learning: Theoretical and conceptual considerations (pp. 155-169). Munster, Germany: Waxmann.

The Design-Based Research Collective (2003). Design-Based Research: An Emerging Paradigm for Educational Inquiry. Educational Researcher, 32(1), 5-8.

Wenger, E. (1998). Communities of practice-learning, meaning and identity. Cambridge: Cambridge University Press. 